\section{References}

Henderson, G., Schiener, E. J., Risum, J. B., Croxton, C. A. \& Anderson, B. B. 1981: The West Greenland Basin. In Kerr, J. W. \& Fergusson, A. J. (edit.) Geology of the North Atlantic borderlands. Mem. Can. Soc. Petrol. Geol. 7, 399428.

Hubbard, R. J., Pape, J. \& Roberts, D. G. 1985: Deposition sequence mapping as a technique to establish tectonic and stratigraphic framework and evaluate hydrocarbon potential on a passive continental margin. In Berg, O. R. \& Woolverton, D. G. (edit.) Seismic stratigraphy II. Mem. Am. Ass. Petrol. Geol. 39, 79-91.

McKenzie, D. P. 1978: Some remarks on the evolution of sedimentary basins. Earth planet. Sci. Lett. 40, 25-32.

Manderscheid, G. 1980: The geology of the offshore sedi- mentary basin of West Greenland. In Miall, A. D. (edit.) Facts and principles of world oil occurrence. Mem. Can. Soc. Petrol. Geol. 6, 951-973.

Srivastava, S. P., Falconer, R. K. H. \& MacLean, B. 1981: Labrador Sea, Davis Strait, Baffin Bay: geology and geophysics - a review. In Kerr, J. W. \& Fergusson, A. J. (edit.) Geology of the North Atlantic borderlands. Mem. Can. Soc. Petrol. Geol. 7, 333-398.

Talwani, M. \& Eldholm, O. 1977: Evolution of the Norwegian - Greenland Sea. Bull. geol. Soc. Amer. 88, 969-999.

Vail, P. R., Mitchum, R. M., Todd, R. G., Widmier, J. M., Thomson, S., Sangree, J. B., Bubb, J. N. \& Hatlelid, W. G. 1977: Seismic stratigraphy and global changes of sea level. In Payton, C. E. (edit.) Seismic stratigraphy - applications to hydrocarbon exploration. Mem. Am. Ass. Petrol. Geol. 26, 49-205.

\title{
Detailed investigation of the niobium-tantalum distribution within the Motzfeldt Centre, South Greenland
}

\author{
Bjørn Thomassen, Tapani Tukiainen and Karsten Secher
}

A one year programme for detailed investigation of selected parts of the Nb-Ta-U-bearing pyrochlore mineralisation within the Motzfeldt Centre, South Greenland, was initiated in June 1987. The aim of the programme is to delineate areas with a potential for highgrade accumulation of Ta-enriched pyrochlore which is important if international exploration and mining activity is to be attracted. It is also important for official decisions in relation to any application for concessionary activity. The programme is carried out as a joint project between GGU and Nunaoil A/S under supervision of GGU, and a major part of the funding is granted by the Mineral Resources Administration for Greenland.

On the basis of information obtained during survey activity from 1980 to 1986 (Tukiainen, 1986), six mineralised areas covering c. $1.5 \mathrm{~km}^{2}$ were selected for detailed investigation by gamma-spectrometry and rock sampling (fig. 1). Most of the areas are situated on very steep slopes in alpine terrain with altitudes up to $1900 \mathrm{~m}$ a.s.l. Therefore, the gamma-spectrometric measurements were made by helicopter, and the sampling was carried out by mountaineers.

In total 20 people were engaged during the field season from the end of June to the end of August (Thomassen \& Tukiainen, 1987). The authors functioned as project geologist, consultant and leader, respectively. The GGU station in Narsarsuaq was operated as the field base by J. Lau. The helicopter service was by Greenlandair Charter A/S, the geophysical survey by Global Earth Sciences Ltd. (England), and the mountaineers were provided by Garaventa AG (Switzerland).

\section{Geology and mineralisation}

The Motzfeldt Centre $(1310 \pm 10 \mathrm{Ma}$, Blaxland et al., 1978 ) is one of the major central complexes in the Gardar Province of alkaline igneous activity. The centre belongs to the Igaliko nepheline syenite complex of which a general account was given by Emeleus \& Harry (1970). Following the discovery of radioactive mineralisation in 1979 (Armour-Brown et al., 1980), the centre has been the objective of intensive research. The detailed geological and radiometric mapping of the Motzfeldt Centre was initiated in 1982 as a part of the 'Syduran project' (Armour-Brown et al., 1983), and gradually its potential for large-scale $\mathrm{Nb}$-Ta mineralisation was recognised (Tukiainen et al., 1984). The research was continued during the project 'Pyrochlore in alkaline intrusions of Greenland' which was partly funded by the European Economic Communities (Bradshaw, 1985; Tukiainen, 1986, in press).

The Motzfeldt Centre covers an area of $c .300 \mathrm{~km}^{2}$. It is made up of multiple intrusions of syenites emplaced into the Proterozoic Julianehåb Granite and the overlying Gardar supracrustal rocks. The main igneous 
Fig. 1. Map of the Motzfeldt Sø area. The Motzfeldt Centre is dark grey, other Gardar intrusions are light grey. The investigated localities are indicated with stars.

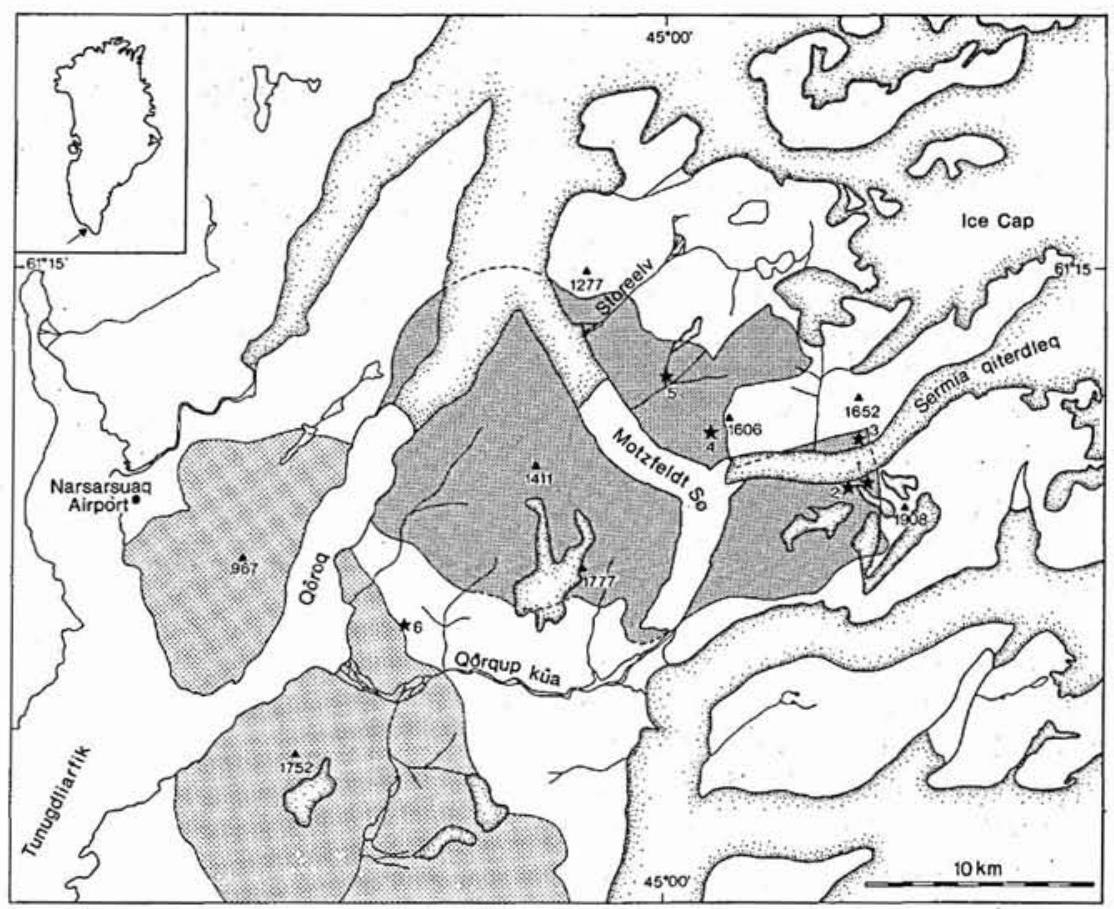

phase (the Motzfeldt Ring Series) consists of a number of largely concentric, steep-sided, outward dipping units of predominantly peralkaline syenite and nepheline syenite which young inwards. It is the outermost of these units, the Motzfeldt $S \varnothing$ Formation, which hosts the mineralisation. The apparent intrusion mechanism was a combination of ring fracture and block subsidence. Post-dating the syenite intrusions the centre was dissected by a number of faults with displacements up to 6 $\mathrm{km}$ horizontally and $600 \mathrm{~m}$ vertically.

Large quantities of roofing sandstones and volcanics have been incorporated into the Motzfeldt Sø Formation. The volcanics are preserved as large rafts, but the sandstones have largely been assimilated and caused an outer zone of the Motzfeldt Sø Formation with a silica saturated composition. The formation underwent an extreme in situ differentiation, probably due to effective crystal fractionation, which resulted in the formation of a peralkaline residuum rich in volatile and incompatible elements. The peralkaline residuum gave rise to a complex of late peralkaline sheets of microsyenite and pegmatite, and to hydrothermal alteration with associated Th-U-Nb-Ta-Zr-REE mineralisation which increases in intensity outwards, especially towards the roof of the intrusion.

The mineralisation is probably the result of a combination of an incompatible element/volatile enriched magmatic residuum and an influx of silica and meteoric water, which resulted in a dramatic increase in oxygen fugacity, acidity, and hydrothermal activity. A volatilesaturated outer shell developed which facilitated the migration, accumulation, and precipitation of the incompatible elements.

The Motzfeldt Sø Formation hosts zones of economically interesting pyrochlore enrichment in altered syenite and in peralkaline microsyenite. The pyrochlore is enriched in Ta, $\mathrm{U}$ and LREE. The Ta content and the $\mathrm{Nb} / \mathrm{Ta}$ ratio of the pyrochlore vary from 1.5 to $10.0 \%$ $\mathrm{Ta}_{2} \mathrm{O}_{5}$ and from 8 to more than 50 , respectively, but in general Ta contents are higher in pyrochlore from altered syenite than in pyrochlore from peralkaline microsyenite. The pyrochlore shows also a marked compositional variation depending on its relative depth in the Motzfeldt Sø Formation. At the deeper levels it is enriched in $\mathrm{Ta}$ and $\mathrm{Ca}$, whereas at the higher levels of the igneous column it is more enriched in $\mathrm{Nb}, \mathrm{U}$ and LREE.

\section{Airborne gamma-spectrometric survey}

A gamma-spectrometric survey of the whole Motzfeldt S $\varnothing$ area in 1982 (Tukiainen et al., 1984) and subsequent research (Tukiainen, 1986) has demonstrated a good correlation between radiometric anomalies with high $U$ content and high U/Th ratio, and pyrochlore mineralisation. In order to outline the anomalies in 
detail and to facilitate the extrapolation of element concentrations beyond the sampled areas, the six most anomalous localities were reflown at the beginning of the season with a more advanced airborne survey system installed in a larger helicopter (fig. 1).

Equipment. The survey system with a total weight of $201 \mathrm{~kg}$ was installed in an Écureuil AS 350 B1 helicopter and consisted of a 256 channel gamma-ray spectrometer with a crystal detector of 16.6 litres of Tl-activated NaI crystals, a data acquisition system with tape deck, a six-channel analogue recorder, radar and barometric altimeters, and a video flight path tracking system. The various items of the survey system were fully synchronized.

Procedure. The survey was carried out by contour flying with a contour spacing of $30 \mathrm{~m}$. The system was flown at a speed of $25-40$ knots $(45-72 \mathrm{~km} / \mathrm{h})$, and an average terrain clearance of $30 \mathrm{~m}$ was attempted. To improve the reliability of the radar altimeter recordings in areas with steep mountain slopes, the altimeter was tilted $c$. $30^{\circ}$ against the mountain face to be surveyed. The fixed position and tilt of the radar altimeter on the pilot's side of the aircraft meant that the survey had to be carried out unidirectionally. In order to improve the spatial resolution of the survey, the counting time was set to 0.5 sec., which was considered adequate for the known high level of radiation and the large detector volume. The airborne system recorded the accumulated counts (total counts, $\mathrm{K}$, Th and $\mathrm{U}$ windows) on magnetic tape together with radar-measured ground clearance, barometric altitude, real time and fiducial number, and generated an analogue chart of these data. The flight paths were recorded by a video camera which was installed below the aircraft. These recordings were used for the final flight path recovery. Navigation was based on contoured orthoscopic aerial photographs at a scale of 1:5000 supplemented by oblique photographs.

The energy calibration of the system was performed with a ${ }^{137} \mathrm{Cs}$ gamma-ray source. The background radiation level and instrumental drift were checked at the beginning and end of each flight. The background radiation test was carried out over sea water, and checks for instrumental drift and determination of the attenuation coefficients were made over a $2.5 \mathrm{~km}$ long test strip. Checks for cosmic radiation were made at the beginning and end of the survey programme.

Results. The survey involved 23 hours 52 minutes of flying time, of which 19 hours 25 minutes were used for the survey proper and the remaining time for attenuation and cosmic tests. A total of 454 line $\mathrm{km}$ were flown, and 63,443 measurements with an average point separation of $c .7 \mathrm{~m}$ were recorded over an area of $c$. $16.3 \mathrm{~km}^{2}$ (Table 1).

A preliminary evaluation and interpretation of the data based on uncorrected raw data from the analogue charts was made immediately after the survey was completed. The anomalies were manually plotted on the flight track maps and used to guide the chip sampling programme.

The final processing by Global Earth Sciences Ltd. included correction of the spectrometric data for background variations, spectral interferences and ground clearance, and merging of this data with navigation information.

\section{Detailed chip sampling}

To obtain reliable data from the best mineralised areas in the Motzfeldt Centre, chip samples were collected systematically at five localities (1-5 on fig.1). At the first four localities the mountains are so steep (slope angles $50^{\circ}-90^{\circ}$ ) that the sampling was performed by six mountaineers under supervision of the project geologist. The group was lodged in a mobile field camp consisting of three caravans. Selection of the localities was based on previous work (Tukiainen, 1986), with the main emphasis on tantalum mineralisation in altered syenite of the Motzfeldt Sø Formation.

Procedure. The mineralised localities were sampled as far as possible on a grid with the grid lines perpendicular to the contours. The spacing between grid lines was originally $50 \mathrm{~m}$ and the vertical distance between sample points in the lines was also $50 \mathrm{~m}$. After the aeroradiometric survey had localized the anomalies, additional sampling on a $25 \times 25 \mathrm{~m}$ grid was performed over the best anomaly at locality 1 (fig. 2), and a $25 \times 25 \mathrm{~m}$ grid was used from the beginning at localities 3 to 5 .

\section{Table 1. Summary of results of aeroradiometric survey and chip sampling in 1987, Motzfeldt Centre, South Greenland}

\begin{tabular}{|c|c|c|c|c|}
\hline \multirow[b]{2}{*}{ Loc. } & \multicolumn{2}{|c|}{ Aeroradiometric survey } & \multicolumn{2}{|c|}{ Chip sampling programme } \\
\hline & $\begin{array}{l}\text { Number of } \\
\text { measurements }\end{array}$ & $\begin{array}{c}\mathrm{km}^{2} \\
\text { covered }\end{array}$ & $\begin{array}{l}\text { Number of } \\
\text { samples }\end{array}$ & $\begin{array}{c}\mathrm{km}^{2} \\
\text { covered }\end{array}$ \\
\hline 1 & 15,017 & 3.4 & 329 & 0.26 \\
\hline 3 & 8,922 & 1.8 & 286 & 0.12 \\
\hline 4 & 10,501 & 3.0 & 145 & 0.07 \\
\hline 5 & 15.257 & 3.3 & 49 & 0.04 \\
\hline 6 & 13,736 & 4.8 & 0 & 0.00 \\
\hline Total & 63,443 & 16.3 & 928 & 0.64 \\
\hline
\end{tabular}




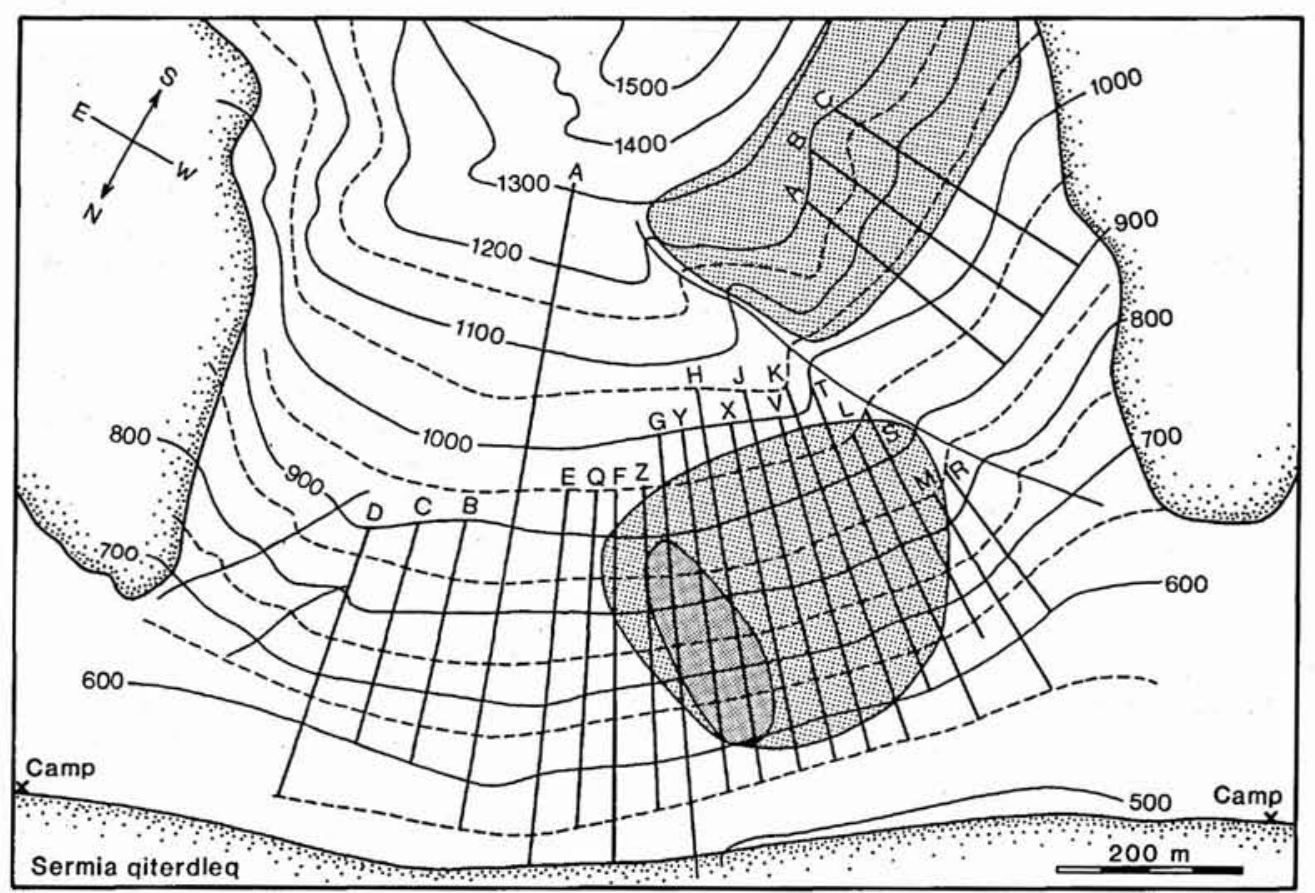

Fig. 2. Map of Qiterdleq South (locality 1). Aeroradiometric anomalies are hatched, and chip sampled grid lines are marked with letters.

The daily sampling started at the top of the anomaly, where the climbers went by helicopter or on foot from the field camp. They measured out the distances between the grid lines and descended over the mountainside in groups of two or three, as far as possible in straight lines. At each sample point (determined by a barometric altimeter) a $2 \times 2 \mathrm{~m}$ cross was spray-painted together with a preliminary number. A chip sample and two small reference samples were collected inside the 4 $\mathrm{m}^{2}$ defined by the cross, and thereafter a scintillometer measurement was performed. Working its way down in this manner, a two man group could typically collect 10 samples during a 10-12 hour working day.

The sample sites were plotted on enlarged oblique photographs by the project geologist from observation points in the middle of the glacier. With a $\times 16$ binocular mounted on a tripod it was possible to locate most sample points, and also to direct the sampling via a portable VHF radio.

In a laboratory established in Narsarsuaq, the chip samples were run through a jaw crusher and a mill, after which $100 \mathrm{~g}$ large splits were shipped directly to two commercial chemical laboratories in Canada. The samples are to be assayed for $\mathrm{Nb}, \mathrm{Ta}, \mathrm{Th}$ and $\mathrm{U}$, and analysed for $\mathrm{Be}, \mathrm{Ce}, \mathrm{La}, \mathrm{Li}, \mathrm{Mo}, \mathrm{Sn}, \mathrm{Y}$ and $\mathrm{Zr}$.
Results. Most of the radiometric anomalies defined in localities 1 to 5 by the aeroradiometric survey were covered by the chip sampling programme. An area with overhanging rock at locality 3 could not be sampled, and at other places a combination of steepness and loose rocks made sampling too dangerous, but on the whole, a satisfactory coverage was obtained at the main targets, localities 1 to 3 . At localities 4 and 5 , where several anomalies occur, the best anomaly was selected for detailed sampling. Locality 6 was not visited.

A total of 928 chip samples were collected over an anomalous area of $0.64 \mathrm{~km}^{2}$ (Table 1). The sample weights ranged from $1.0 \mathrm{~kg}$ to $2.5 \mathrm{~kg}$ with an average of $1.8 \mathrm{~kg}$.

\section{Additional sampling}

Bulk sample. With a view to possible beneficiation tests, a $200 \mathrm{~kg}$ sample was collected by means of drilling and blasting at locality 1 . It consists of relatively fresh aplitic microsyenite or syenite with a high radiation.

Alluvial sands. In order to evaluate the Nb-Ta-mineral placer potential, 10 litre sediment samples were collected from the main drainage systems and the plains bordering Motzfeldt $\mathbf{\varnothing}$. Heavy mineral concentrates 
were panned out from 29 stream-sediment samples, while four samples from a large glaciofluvial plain will be analysed untreated.

\section{Concluding remarks}

The aeroradiometric survey successfully reduced the areal extent of the previously known gamma anomalies by about $50 \%$. This was due to the use of equipment with better resolution and a helicopter with better performance, compared with the 1982 survey. Consequently, smaller areas had to be covered by the systematic chip sampling, which enabled the collection of larger samples in closer spaced grids than originally planned.

The acquired geophysical and geochemical data will be treated statistically in co-operation with IMSOR (Institute of Mathematical Statistics and Operations Research), Technical University of Denmark, and will be interpreted in a final report.

Acknowledgements. The authors thank J. Lau and O. Plesner for invaluable support from the base camp at Narsarsuaq; E. Dam and I. Rytved for their spirited contribution in the field laboratory; L. Thorning for assistance during the geophysical survey; J. L. Pedersen and L. Melchior Larsen for comments on the report; and finally the Swiss mountaineering team and the British geophysical staff for professional and enjoyable co-operation.

\section{References}

Armour-Brown, A., Tukiainen, T. \& Wallin, B. 1980: The South Greenland regional exploration programme. Rapp. Grønlands geol. Unders. 100, 83-86.

Armour-Brown, A., Tukiainen, T., Wallin, B., Bradshaw, C., Emeleus, C. H. 1983: Uranium exploration in South Greenland. Rapp. Grønlands geol. Unders. 115, 68-75.

Blaxland, A. B., van Breemen, O., Emeleus, C. H. \& Anderson, J. G. 1978: Age and origin of the major syenite centres in the Gardar province of South Greenland: $\mathrm{Rb}-\mathrm{Sr}$ studies. Bull. geol. Soc. Am. 89, 231-244.

Bradshaw, C. 1985: The alkaline rocks of the Motzfeldt Centre; progress report on the 1984 field season. Rapp. Grønlands geol. Unders. 125, 62-64.

Emeleus, C. H. \& Harry, W. T. 1970: The Igaliko nepheline syenite complex. General description. Bull. Grønlands geol. Unders. 85 (also Meddr Grønland 186,3) 116 pp.

Thomassen, B. \& Tukiainen, T. 1987: The Motzfeldt 87 project. Field report. Unpubl. intern. GGU rep., 16 pp.

Tukiainen, T. 1986: Pyrochlore in the Motzfeldt Centre of the Igaliko nepheline syenite complex, South Greenland. Final Report. Unpubl. intern. GGU rep., 98 pp.

Tukiainen, $T$. in press: Niobium-tantalum mineralisation in the Motzfeldt Centre of the Igaliko nepheline syenite complex, South Greenland. Spec. Publ. Soc. Geol. Appl. Min. Dep. 5. Tukiainen, T., Bradshaw, C. \& Emeleus, C. H. 1984: Geological and radiometric mapping of the Motzfeldt Centre of the Igaliko Complex, South Greenland. Rapp. Grønlands geol. Unders. 120, 78-83.

\title{
Greenland ice cap aeromagnetic survey 1987: completion of the survey over the southern end of the Greenland ice cap
}

\author{
L. Thorning, M. Bower, C. D. Hardwick and P. Hood
}

The Geological Survey of Greenland (GGU), the Geological Survey of Canada (GSC), and the National Aeronautical Establishment (NAE) of the National Research Council of Canada are cooperating in the GICAS project. The objective of the project is to achieve a regional, aeromagnetic coverage of the Greenland ice cap, and to produce magnetic anomaly maps for use in research on the large scale geological structures. Field work was carried out in 1983, 1984, and 1985 (Thorning et al. , 1984, 1985, 1986). The work reported in this note was originally planned for April 1986, but for technical reasons it had to be postponed until April 1987. Consequently, the subsequent processing of all the data into a regional magnetic anomaly map has been correspondingly delayed.

\section{Field work}

In 1985 parts of the southernmost ice cap were covered (Thorning et al., 1986), and the 1987 operation was planned to make the coverage complete over this part of the ice cap. The operation was carried out as part of a larger programme to compile a magnetic anomaly map of North America, which also involved work in northern Canada and the Nares Strait region between Canada and Greenland, and a tie-line from the North Greenland continental shelf over the ice cap along its western margin to Søndre Strømfjord. Tie-lines from Alert to Svalbard to Iceland had to be abandoned due to unfavourable weather conditions around Svalbard.

The flights for the GICAS were based at Søndre 